\title{
Trade in Services and the World Economy : An American Point of View *
}

\author{
by Reubin D. Askew **
}

Steel, Autos, Sugar, Grain, Textiles: These are typical of the usual topics of International Trade Negotiations. For decades, the ongoing debate over world trade has focused almost exclusively on trade in goods and commodities. The series of multilateral negotiating rounds which has guided the growth of much of the global economy since World War II has consistently emphasized the tangible, visible products which are the objects of much of world trade.

But there is another kind of trade. There are other kinds of products. And international trade in these other, intangible products is increasingly vital to the well-being of the world economy.

I speak of trade in services - of commerce in banking, construction, engineering, advertising, insurance, health care, transportation, data processing, accounting, and numerous other invisible but often essential products.

Trade in services has long been overlooked. But recent developments make it unlikely that such trade will be overlooked much longer.

Foremost among those developments is the growing market for services in world commerce. In the past decade, the value of world trade in services rose from $\$ 85$ Billion to $\$ 300$ Billion. In the past three years, trade in services has grown at more than twice the rate of the growth of trade in goods. Already, services account for about one-fourth of the value of all international trade. And this fraction seems likely to increase.

As trade in services has become more important to the world, it has become more important also to developed nations such as the United States. Services new account for seven of every ten American jobs and for more than half of the American gross national product.

Other nations now pay the United States $\$ 60$ Billion each year for a multitude of services - thus accounting for nearly one-third of American exports and for about 20 percent of the current world services trade. We have had an overall surplus in our balance of payments in the United States recently only because our surpluses in receipts

* Presented at the Eagle Lodge (Philadelphia) Conference of the Geneva Association, 29/30 April 1982.

** Former U.S. Trade Representative and Governor of Florida. 
from trade in services have offset our continuing deficits in receipts from trade in merchandise.

The United States has the largest service economy in the world. But other nations are also increasingly dependent on services. And these other service-oriented nations share with the United States a common interest in facilitating the exchange of services across national borders by giving issues related to trade in services the prominent international attention they deserve.

Such multilateral attention would come none too soon. For barriers to trade in services are many and multiplying. As trade deliberations have centered through the years on lowering tariff and non-tariff barriers to trade in goods, a vast array of obstacles to trade in services has emerged and become entrenched in dozens of nations around the world. And, as the importance of services has become more apparent, still more barriers have been erected against the free flow of services in world commerce.

These impediments to trade in services assume many forms and operate in many ways. They affect a variety of industries. But generally they either limit the access of foreign suppliers to a national market or discriminate against the activities of foreign suppliers once they are established within a national market.

For example : It has been very difficult for U.S. insurers to operate effectively in Japan, in large part because of the reluctance of Japanese regulators to approve new forms of insurance and to license new insurers promptly.

Bolivia and Peru charge U.S. airlines higher prices for fuel than they charge their own national carriers.

Norway has not granted a license to a foreign insurance company in forty years.

Australia will not allow foreign banks to open branches or subsidiaries.

Argentina requires car importers to insure their shipments with Argentine insurance companies.

Sweden bars local offices of foreign companies from processing payrolls abroad. carriers.

Japanese airliners get their cargo cleared more quickly in Tokyo than do foreign

If a U.S. company wants to use American models for an advertisement in a West German magazine, it has to hire the models through a German agency - even if the ad is being photographed in the United States.

And, as I recall only too well from my service as United States Trade Representative, Canada gives Canadian businesses a tax break for advertising on Canadian Radio and Television Stations, but not for advertising on U.S. stations.

I could go on. During my tenure as Trade Representative, I asked my staff to compile a liste of the barriers to trade in services worldwide. That list is now complete. It is 210 pages long and includes more than 2.000 examples.

The effect of this particular form of protectionism is precisely the same as the effect of any other form of protectionism. It diminishes competition, encourages inefficiency, hinders productivity, and increses prices. It keeps us from pursuing in a rational way our common goals of greater economic growth and enhanced economic development for trading nations. 
The United States is not entirely blameless in this proliferation of barriers to trade in services. No nation is immune to the lure of protectionism. But generally the United States has adhered to a policy of open markets in the services trade. Unlike some, we do not end to discriminate against most foreign service industries.

But what worries most American firms most at this time is not so much the continuing disparity between the relatively open services market in the United States and the relatively restricted markets abroad as the alarming fact that barriers to trade in services elsewhere are growing in both their scope and their severity. In a recessionary climate characterized by slow growth and widespread economic uncertainty, many nations are yielding to the protectionnist impulse where trade in services is concerned.

In particular, there is increasing concern in the United States about possible restrictions on the flow of computerized data across national lines. For example, West Germany informed computer time-sharing bureaus that their licenses will not be renewed unless their data processing takes place within West German borders. And France is reportedly considering the imposition of import duties on computer software.

The prospect of increased barriers affecting telecommunications and data processing has far-ranging implications in a world on the verge of what many have described as an "information revolution". Questions of privacy rights and national security aside, the world can ill afford needless restrictions on the international flow of computerized information.

Nor should we expect that the impact of such restrictions would be limited to the telecommunications and data processing industries alone. A rash of restrictions on the international transmission of data would have an enormously disruptive impact on many aspects of international trade in goods and services alike.

This issue, perhaps more than any other, has persuaded government officials in Washington of both the importance and the complexity of dealing forthrightly with the many issues posed by barriers related to trade in services. And I for one wish to publicly applaud my successor, Ambassador Bill Brock, for all he has done to build on the preliminary work we began on services issues while I was United States Trade Representative.

As I anticipated, and as Ambassador Brock has said many times himself, building a constituency for addressing services issues will not be easy. In all likelihood, it will take a long time. But the stakes are well worth the effort, both for the United States and for other trading nations as well. And we can no longer afford to ignore the mounting obstacles to international trade in services.

A national constituency for addressing these invisible barriers to this invisible trade is rapidly emerging in the United States. In recent years, the American business community has come to appreciate the crucial importance of services exports to the American economy. And now Congress is looking for ways to confront services issues as well.

My close friend from Florida, Congressman Sam Gibbons, and several other members of the Congress have introduced legislation to build on the provisions of the trade act of 1974 which first enabled the executive branch of the Federal Government to deal with services issues. Key provisions of these bills would increase the priority 
accorded to reducing service trade barriers, encourage the elimination of needless disincentives to services exports, strengthen the mandates of the United States Trade Representative and the Department of Commerce for Addressing Services Questions, and broaden the remedies available to U.S. service companies for dealing with unfair trade practices.

Meanwhile, the executive branch, to its credit, is continuing to press for the removel of barriers to services trade on a bilateral basis. This can sometimes be successful, as I learned when I was able to persuade the South Koreans to liberalize restrictions which prevented foreign insurers from selling policies in that country.

But, ideally, barriers to trade in services should be assailed, not on a bilateral, but on a multilateral basis. The common interest of trading nations in eliminating needless hindrances to services trade should be translated into common action by the General Agreement on Tariffs and Trade - the GATT in Geneva which establishes the governing rules for much of world trade.

With this in mind, I find it encouraging that the 24-Nation Organization for Economic Cooperation and Development is compiling an inventory of regulatory restrictions to trade in services. Conceivably, this OECD list could become the basis for negotiations leading to international guidelines for services trade, in much the same way as a list of nontariff barriers compiled by the GATT Council in the 1960's formed the basis for the codes of conduct limiting nontariff barriers to trade in goods which eventually emerged from the Tokyo Round in 1979.

I find it encouraging as well that the United States Government has proposed including trade in services on the agenda of the GATT Ministerial Conference scheduled for Geneva in late November. Like our Government, I do not believe for a moment that all these difficult services issues will be resolved this year. It will take much longer than that. But inclusion of services issues on the Conference agenda will at least assure a departure from the traditional near-exclusive concentration of the GATT on merchandise trade.

The time has come for the world trading community to extend to trade in services the principles which have long guided our efforts internationally to manage trade in goods. During this time of rising protectionist sentiment worldwide, we must be as diligent in our efforts to contain protectionism in trade in services as we have been and must continue to be in our efforts to contain protectionism in trade in goods.

Substantial liberalization of world trade in services should not only be on the agenda of the GATT. It should be high on that agenda.

As it is, the GATT barely acknowledges even the existence of trade in services. Changing this will undoubtedly give rise to countless technical questions and endless technical questions and endless technical difficulties. But, however services issues may eventually be addressed within the GATT framework, whether in the form of separate codes or otherwise, this should not be allowed to obscure the fact that there must be an international regime designed to minimize discrimination and facilitate more open services trade.

For the truth is, we simply cannot hope to maintain an open trading system if we exclude from that system an element which accounts for one-fourth of world trade 
and, moreover, is the fastest growing component of world trade. Protectionist tendencies in services cannot help but spill over into trade in goods, thus complicating worldwide commercial problems which are already complicated enough.

Dealing with services issues is clearly in the common interest of all the nations of the world trading community. It is in the interest not only of such nations as the United States which are already competitive in many services sectors, but also of all those other nations which rely on services and are competitive in services now or will become increasingly involved in services as their economies continue to mature.

Moreover, even those nations which for some reason may feel they will never be services exporters share also in the common international stake in addressing services issues. Their ability to export tangible goods and commodities to services-oriented nations is likely to depend increasingly on the ability of those other nations to trade with them. And much of that return trade will, of necessity, have to be in services.

So we must adopt a broader perspective. We cannot separate services from the rest of the world trading system. And we cannot expect that system to evolve as it should, we cannot continue our progress toward a mutually profitable and mutually productive trading system in which all nations do what they do best, unless services issues are given the attention they deserve.

To date, the emerging national constituency in the United States for dealing with barriers to trade in services has not been matched by an emerging international constituency. Thus far, the international reaction to the American initiative has been cautious and somewhat skeptical.

Obviously, the challenge for the United States is to help our trading partners appreciate our common interest in liberalization of trade in services. One that challenge is met, I am confident we will construct the durable international framework we need to deal with the vast array of service issues.

This much is certain. We cannot continue as we are. If trade issues are to be managed as they must be managed in this time of instability and discord, then the apparatus of the world trading system must be altered to account for the new realities of world commerce. Of necessity, this implies a multilateral effort to confront not only the many issues raised by trade in goods, but also those related to trade in services. 